\title{
PENGARUH SANKSI PERPAJAKAN TERHADAP KEPATUHAN WAJIB PAJAK DIMODERASI BUDAYA BUGIS MAKASSAR PADA KANTOR PELAYANAN PAJAK MAKASSAR SELATAN
}

\author{
Muhummad Rusyidi' ${ }^{1}$, Nurhikmah ${ }^{2}$ \\ Universitas Muhammadiyah Makassar \\ Email: ${ }^{1}$ muhammadrusyidi@unismuh.ac.id, ${ }^{2}$ nurhikmah@unismuh.ac.id
}

\begin{abstract}
This study aims to determine the level of personal taxpayer compliance in the South Makassar Primary Tax Office, by reinforcing tax sanctions and strengthened by the culture of Siri Na Pacce so that it will affect the awareness of taxpayers to pay taxes. The type of research used is quantitative descriptive research. The results of the study concluded that the tax sanctions have a significant positive effect on the level of personal taxpayer compliance in the South Makassar Primary Tax Office and reinforced by the taxpayer's own culture that is a thick culture called siri na pacce on taxpayers themselves.
\end{abstract}

Keywords : Tax sanctions, culture, and taxpayer compliance.

\begin{abstract}
Penelitian ini bertujuan untuk mengetahui tingkat kepatuhan wajib pajak orang pribadi di Kantor Pelayanan Pajak Pratama Makassar Selatan, dengan mempertegas sanksi perpajakan serta di perkuat oleh budaya siri na pacce sehingga akan mempengaruhi kesadaran wajib pajak untuk membayar pajaknya. Jenis penelitian yang digunakan adalah penelitian deskriptif kuantitatif. Hasil penelitian menunjukkan bahwa sanksi perpajakan berpengaruh signifikan positif pada tingkat kepatuhan wajib pajak orang pribadi di KPP Pratama Makassar Selatan serta diperkuat oleh budaya wajib pajak itu sendiri yaitu budaya yang kental disebut siri na pacce pada diri wajib pajak.
\end{abstract}

Keywords: sanksi pajak, budaya, dan kepatuhan wajib pajak. 


\section{PENDAHULUAN}

Pajak merupakan sumber pendanaan dalam melaksanakan tanggung jawab negara untuk mengatasi masalah sosial, meningkatkan kesejahteraan dan kemakmuran serta menjadi kontrak sosial antara warga negara dengan pemerintah (Ruyadi, 2009). Dalam publikasi Kementerian Keuangan Republik Indonesia mengenai APBN 2016 pajak merupakan sumber pendapatan terbesar bagi negara yaitu $75 \%$ atau $\mathrm{Rp} 1.360,2$ triliun dari total pendapatan negara. Sebagai salah satu unsur penerimaan negara, pajak memiliki peran yang sangat besar dan semakin diandalkan untuk kepentingan pembangunan dan pengeluaran pemerintah (Supadmi, 2009). Penerimaan pajak sangat dipengaruhi oleh pertumbuhan ekonomi suatu negara karena pertumbuhan ekonomi akan meningkatkan pendapatan masyarakat sehingga masyarakat mempunyai kemampuan secara finansial untuk membayar pajak (Sri, 2011)

Pembayaran pajak merupakan kontribusi terbesar bagi suatu negara dan sumber utama pendapatan negara dalam pembiayaan pemerintah dan pembangunan. Tanggung jawab atas kewajiban pembayaran pajak didasari sebagai cerminan kepedulian wajib pajak (Candra, Wibisono, dan Mujilan, 2013). Pembayaran pajak bertujuan meningkatkan kesejahteraan rakyat melalui peningkatan perbaikan dan sarana publik. Alokasi pajak tidak hanya diberikan kepada rakyat yang membayar pajak tetapi juga untuk kepentingan rakyat yang tidak membayar pajak (Lingga, 2012). Permasalahan yang sering terjadi berkaitan dengan pungutan pajak ini yakni masih banyaknya masyarakat yang tidak mau memenuhi kewajiban pajaknya, atau dengan kata lain masih banyaknya tunggakan pajak. Menurut Nugraha (2015) Tingkat kepatuhan wajib pajak orang pribadi (WPOP) untuk menunaikan kewajiban pembayaran pajaknya di Indonesia masih cukup rendah.

Self Assessment System merupakan suatu sistem pemungutan pajak yang memberikan wewenang kepada Wajib Pajak untuk menentukan sendiri jumlah pajak terutang setiap tahunnya sesuai dengan Ketentuan Perundang-undangan yang berlaku. Prinsip self assessment system, telah merubah paradigma pajak selama ini sehingga pembayaran pajak tidak lagi dianggap sebagai beban melainkan sebagai tugas kenegaraan yang harus dipenuhi. Self assessment system memungkinkan adanya wajib pajak yang tidak melaksanakan kewajiban perpajakannya akibat dari kelalaian, kesengajaan atau mungkin ketidaktahuan wajib pajak terhadap kewajiban perpajakannya. Agar self assessment system ini berjalan dengan efektif maka sudah selayaknya kepercayaan tersebut diimbangi dengan upaya penegakan hukum dan pengawasan yang ketat atas kepatuhan wajib pajak dalam melaksanakan kewajiban perpajakannya.

Ketentuan umum perpajakan terkait dengan sanksi perpajakan telah diatur dalam UU. Sanksi pajak diberikan untuk memberikan pelajaran bagi pajak yang melanggarnya. Dengan demikian, diharapkan wajib pajak patuh terhadap peraturan perpajakan dan meminimalisir pelanggaran. Wajib pajak akan berusaha memenuhi kewajiban pajaknya jika memandang sanksi pajak akan lebih merugikannya (Jatmiko, 2009). Penelitian yang dilakukan oleh (Purnomo dalam Supadmi, 2010) menemukan bahwa sanksi pajak berpengaruh secara positif terhadap kepatuhan wajib pajak. Hasil peneitian Yadnyana (2009) dalam Muliari dan dan Setiawan menemukan bahwa sanksi pajak mempunyai pengaruh positif terhadap kepatuhan wajib pajak.

Praktik perpajakan yang sehat tidak hanya mengandalkan kekuatan sistem yang berorientasi pada optimalisasi perolehan pajak, di dalamnya terdapat nilai-nilai moral kebudayaan yang turut melengkapi atau bahkan memperkuat keberadaan sistem perpajakan, sistem perpajakan harus berdimensi nilai moral dan budaya agar praktik perpajakan keluar dari kesan kaku, mekanistis, dan prosedural. Pendekatan moral dalam pajak sesungguhnya diperlukan agar kepatuhan dan ketaatan membayar pajak hadir dari inisiatif atau motif yang tulus dan bukan berdasar atas paksaan atau ancaman (Ardi, 2012:313). Terdapat kecenderungan adanya peraturan (hukum) dan budaya masyarakat untuk meloloskan diri dari pembayaran pajak karena membayar pajak adalah suatu aktivitas yang tidak lepas dari kondisi perilaku (kebiasaan) wajib pajak itu sendiri (Widodo, 2010:8).

Di wilayah Sulawesi Selatan upaya untuk meningkatkan kepatuhan wajib pajak orang pribadi (WPOP) khususnya pada Kantor Pelayanan Pajak Makassar Selatan dirasa masih belum maksimal. Karena masih ada Wajib 
Pajak yang tidak memenuhi kewajibannya, sehingga sanksi pajak diberikan untuk memberikan pelajaran atau hukuman bagi wajib pajak yang melanggarnya, selain dari itu budaya yang kental dengan budaya makassar salah satu diantaranya budaya siri' na pacce juga dapat mempengaruhi tingkat kepatuhan wajib pajak orang pribadi, dengan landasan budaya siri' na pacce akan berpengaruh terhadap kesadaran wajib pajak orang pribadi yang merasa malu ketika tidak membayarkan pajak pribadinya dan mendapat sanksi atas ketidakpatuhannya dalam membayar pajak pribadinya. Dari falsafah hidup masyarakat Makassar inilah yang sarat dengan nilai-nilai positif, sekiranya dapat ditanamkan oleh manusia yang berbudaya. Sehingga adanya sanksi pajak dengan landasan budaya bugis makassar (siri' na pacce) yang dijadikan sebagai dasar kebudayaan yang patuh pada aturan negara dimana ketika individu tersebut melanggarnya maka timbul rasa malu pada individu wajib pajak itu sendiri, sehingga hal tersebut dapat mempengaruhi tingkat kepatuhan wajib pajak orang pribadi.

\section{TINJAUAN PUSTAKA}

\section{Pajak}

a. Pengertian Pajak

Istilah pajak ialah iuran yang dipaksakan, meskipun memiliki pengertian dan penjelasan yang berbeda-beda dari sudut pandang masalah, tujuan dan kegunaan pajak itu sendiri adalah sama. Pajak adalah Iuran rakyat pada kas Negara berdarsarkan undang-undang (yang dapat dipaksakan dengan tidak mendapat jasa timbal balik (kontraprestasi) yang langsung dapat ditunjukkan dan yang digunakan untuk membayar pengeluaran umum" (Mardiasmo, 2011:1).

Definisi pajak menurut Prof. DR. Rochmat Soemitro, SH, (Resmi, 2013), pajak adalah iuran rakyat kepada kas negara berdasarkan undang-undang (yang dapat dipaksakan) dengan tidak mendapat jasa timbal balik (kontraprestasi) yang langsung dapat ditunjukkan, dan yang digunakan untuk membayar pengeluaran umum. Unsur-unsur pokok (Mardiasmo, 2011) dari definisi diatas, yaitu : (1) iuran dari rakyat kepada negara, (2) pajak dipungut berdasarkan Undang-Undang serta aturan pelaksanaannya, (3) tidak ada jasa timbal balik atau kontraprestasi dari negara, dan
(4) digunakan untuk membiayai pengeluaranpengeluaran negara yang bermanfaat bagi masyarakat luas.

Definisi pajak menurut S. I. Djajadiningrat (Resmi, 2013), pajak sebagai suatu kewajiban menyerahkan sebagian dari kekayaan ke kas negara yang disebabkan suatu keadaan, kejadian, dan perbuatan yang memberikan kedudukan tertentu, tetapi bukan sebagai hukuman, menurut peraturan yang ditetapkan pemerintah serta dapat dipaksakan, tetapi tidak ada jasa timbal balik dari negara secara langsung untuk memelihara kesejahteraan secara umum.

Berdasarkan Undang-Undang No 16 Tahun 2009 Ketentuan Umum Perpajakan Pasal 1 ayat 1 pajak adalah: kontribusi wajib kepada negara yang terutang oleh pribadi atau badan yang bersifat memaksa berdasarkan undang-undang, dengan tidak mendapatkan imbalan secara langsung dan digunakan untuk keperluan negara bagi sebesar-besarnya kemakmuran rakyat. Oleh karena itu pajak memegang peranan yang penting dalam pembangunan suatu daerah (Siahaan, 2010). Pajak adalah iuran kepada Negara (yang dapat dipaksakan) yang terutang oleh yang wajib membayarnya menurut peraturanperaturan, dengan tidak mendapat prestasi kembali, yang langsung dapat ditunjuk, dan yang gunanya adalah untuk membiayai pengeluaran-pengeluaran umum berhubung dengan tugas Negara yang menyelenggarakan Pemerintahan (Waluyo, 2008:2).

\section{b. Pengelompokan Pajak}

Pembagian pajak menurut Mardiasmo (2011:5) dapat digolongkan menurut golongannya, sifat, dan lembaga pemungutnya. Lebih rincinya adalah sebagai berikut:

1) Menurut golongannya

a) Pajak langsung adalah pajak yang harus dipikul sendiri oleh wajib pajak dan tidak dapat dibebankan atau dilimpahkan kepada orang lain. Contoh: pajak penghasilan (PPh).

b) Pajak tidak langsung adalah yaitu pajak yang pada akhirnya dapat dibebankan atau dilimpahkan kepada orang lain. Contohnya: pajak pertambahan nilai ( $\mathrm{PPN}$ ).

2) Menurut sifatnya

a) Pajak subjektif adalah pajak yang berpangkal atau berdasarkan pada subjeknya, dalam arti memperhatikan 
keadaan diri wajib pajak. Contoh: pajak penghasilan.

b) Pajak objektif adalah pajak yang berpangkal pada objeknya, tanpa memperhatikan keadaan sendiri wajib pajak. Contoh: PPN dan PPnBM.

3) Menurut lembaga pemungutnya

a) Pajak pusat adalah pajak yang dipungut oleh pemerintah pusat dan digunakan untuk membiayai rumah tangga negara.

b) Pajak daerah adalah yaitu pajak yang dipungut oleh pemerintah daerah dan digunakan untuk membiayai rumah tangga daerah.

c. Fungsi Pajak

Pada dasarnya pajak berfungsi sebagai sumber pendapatan negara. Fungsi pajak ada dua (Mardiasmo, 2011: 1) yaitu:

1) Fungsi penerimaan (budgetair) Pajak sebagai sumber dana bagi pemerintah untuk membiayai pengeluaran-pengeluarannya.

2) Fungsi mengatur ( regulerend ) Pajak sebagai alat untuk mengatur atau melakukan kebijaksanaan pemerintah dalam bidang soial dan ekonomi.

\section{d. Syarat Pemungutan Pajak}

Agar pemungutan pajak tidak menimbulkan hambatan atau perlawanan maka diperlukan syarat-syarat dalam pemungutan pajak. Dalam pemungutan pajak ada lima syarat yang harus diperhatikan (Mardiasmo, 2011:2 ) yaitu:

1) Pemungutan pajak harus adil (syarat keadilan) Sesuai dengan tujuan hukum, yakni mencapai keadilan, undangundang dan pelaksanaan pemungutan harus adil. Adil dalam perundang-undangan diantaranya mengenakan pajak secara umum dan merata, serta disesuaikan dengan kemampuan masing-masing.

2) Pemungutan pajak harus berdasarkan undang-undang (syarat yuridis) Di Indonesia, pajak diatur dalam UUD 1945 pasal 23 ayat 2 . Hal ini memberikan jaminan hukum untuk menyatakan keadilan, baik bagi negara maupun warganya.

3) Tidak mengganggu perekonomian (syarat ekonomi) Pemungutan tidak mengganggu kelancaran kegiatan produksi maupun perdagangan, sehingga tidak menimbulkan kelesuan perekonomian masyarakat.
4) Pemungutan pajak harus efisien (syarat finansil) Sesuai fungsi budgetair, biaya pemungutan pajak harus dapat ditekan sehingga lebih rendah dari hasil pemungutannya.

5) Sistem pemungutan harus sederhana Sistem pemungutan yang sederhana akan memudahkan dan mendorong masyarakat dalam memenihi kewajiban perpajakannya.

e. Sistem Pemungutan Pajak

Sistem pemungutan pajak dapat dibagi menjadi tiga sistem (Mardiasmo, 2011:7), sebagai berikut.

1) Official Assessment system adalah suatu sistem pemungutan yang memberi wewenang kepada pemerintah (fiskus) untuk menentukan besarnya pajak yang terutang oleh Wajib Pajak. Ciri-cirinya :

a) Wewenang untuk menentukan besarnya pajak terutang ada pada fiskus.

b) Wajib pajak bersifat pasif.

c) Utang pajak timbul setelah dikeluarkan surat ketetapan pajak oleh fiskus.

2) Self Assessment System adalah suatu sistem pemungutan yang memberi wewenang sepenuhnya kepada Wajib Pajak untuk menghitung, memperhitungkan, membayar, dan melaporkan sendiri besarnya pajak yang terutang. Ciri-cirinya :

a) Wewenang untuk menentukan besarnya pajak terutang ada pada Wajib Pajak sendiri.

b) Wajib pajak aktif, mulai dari menghitung, menyetor dan melaporkan sendiri pajak yang terutang.

c) Fiskus tidak ikut campur dan hanya mengawasi

3) With Holding System adalah suatu sistem pemungutan yang memberi wewenang kepada pihak ketiga (bukan fiskus dan bukan wajib pajak yang bersangkutan) untuk menentukan besarnya pajak yang terutang oleh wajib pajak.

f. Teori Pendukung Pemungutan Pajak

Menurut Mardiasmo (2011:3) beberapa teori yang menjelaskan atau memberikan justifikasi pemberian hak kepada negara untuk memungut pajak. Teori-teori tersebut antara lain:

1) Teori asumsi

Negara melindungi keselamatan jiwa, harta benda, dan hak-hak rakyatnya. Oleh karena itu 
rakyat harus membayar pajak yang diibaratkan sebagai suatu premi asuransi karena memperoleh jaminan perlindungan tersebut.

\section{2) Teori kepentingan}

Pembagian beban pajak kepada rakyat didasarkan pada kepentingan (misalnya perlidungan ) masing-masing orang. Semaki besar kepentingan seseorang terhadap negara, makin tinggi pula pajak yang harus dibayar.

\section{3) Teori daya pikul}

Beban pajak untuk semua orang harus sama beratnya, artinya pajak harus dibayar sesuai dengan dayan pikul masing-masing orang. Untuk mengukur daya pikul dapat digunakan dua pendekatan yaitu: a) Unsur objektif, dengan melihat besarnya penghasilan atau kekayaan yang dimiliki oleh seseorang; b) Unsur subjektif, dengan memperhatikan besarnya kebutuhan materiil yang harus dipenuhi.

\section{4) Teori bakti}

Dasar keadilan pemungutan pajak terletak pada hubungan rakyat dengan negaranya. Sebagai warga negara yang berbakti, rakyat harus selalu menyadari bahwa pembayaran pajak adalah sebagai suatu kewajiban.

\section{5) Teori asas daya beli}

Dasar keadilan terletak pada akibat pemungut pajak. Maksudnya memungut pajak berarti menarik daya beli dari rumah tangga masyarakat untuk rumah tangga negara. Selanjutnya negara akan menyalurkannya kembali ke masyarakat dalam bentuk pemeliharaan kesejahteraan masyarakat.

\section{g. Tarif Pajak}

Mardiasmo (2011:9) mengemukankan empat macam tarif pajak. Keempat tarif tersebut dapat dijelaskan sebagai berikut:

1) Tarif sebanding/proporsional yaitu tarif berupa persentase yang tetap, terdapat berapapun jumlah yang dikenai pajak sehingga besarnya pajak yang terutang proporsional terhadap besarnya nilai yang dikenai pajak.

2) Tarif tetap yaitu tarif berupa jumlah yang tetap (sama) terhadap berapapun jumlah yang dikenai pajak sehingga besarnya pajak yang terutang tetap.
3) Tarif progresif yaitu tarif yang digunakan semakin besar bila jumlah yang dikenai pajak semakin besar.

Tabel 1. Tarif Pajak

\begin{tabular}{ll}
\hline Penghasilan kena pajak & Tarif pajak \\
\hline Sampai dengan Rp.50.000.000,00 & $5 \%$ \\
\hline Di atas Rp.50.000.000 s.d Rp.250.000.000 & $15 \%$ \\
\hline Di atas Rp.250.000.000 s.d 500.000.000 & $25 \%$ \\
\hline Di atas 500.000.000 & $30 \%$ \\
\hline
\end{tabular}

h. Sanksi Perpajak

Menurut Mardiasmo (2011) sanksi perpajakan merupakan jaminan bahwa ketentuan peraturan perundang-undangan perpajakan (norma perpajakan) akan dituruti atau dipatuhi atau dengan kata lain, sanksi perpajakan merupakan alat pencegah (preventif) agar wajib pajak tidak melanggar norma perpajakan.

\section{i. Jenis-jenis Sanksi Perpajakan}

Menurut Purwono (2010:68) berdasarkan jenisnya, "sanksi di bidang perpajakan dapat dikelompokkan menjadi dua kategori yaitu sanksi administrasi dan sanksi pidana”.

Sanksi administrasi merupakan pembayaran kerugian terhadap negara yang bisa berupa denda administrasi, bunga, atau kenaikan pajak yang terutang. Sanksi administrasi ditekankan kepada pelanggaran-pelanggaran administrasi perpajakan yang tidak mengarah kepada tindak pidana perpajakan (Purwono, 2010 :68). Sanksi pajak yang dimaksud dalam hal ini berupa sanksi yang dikenakan kepada wajib pajak orang pribadi apabila tidak memenuhi kepatuhan pajak dalam melaporkan SPT/ mengalami keterlambatan dalam pelaporan SPT tahunan, adapun denda yang dikenakan kepada wajib pajak orang pribadi untuk keterlambatan pelaporan SPT pajak tahunan sebanyak Rp 100.000 per tahun sanksi pidana merupakan upaya terakhir dari pemerintah agar norma perpajakan benar-benar dipatuhi. Sanksi pidana ini bisa timbul karena adanya tindak pidana pelanggaran yaitu tindak pidana yang mengandung unsur ketidak sengajaan atau kealpaan, atau dikarenakan adanya tindak pidana kejahatan yaitu tindak pidana yang mengandung unsur kesengajaan atau kelalaian/pengabaian. Sedangkan ancaman sanksi pidana dapat berupa denda pidana, pidana kurungan, atau pidana penjara (Purwono, 2010 :68). 


\section{Kebudayaan}

a. Pengertian Budaya

Kata "budaya" berasal dari bahasa sansekerta buddhayah yang merupakan bentuk jamak dari kata buddhi, yang berarti "budi" atau "kaal". Kebudayaan itu sendiri diartikan sebagai " hal-hal yang berkaitan dengan budi atau akal". Hal ini sesuai pandangan Ruth Benedict dalam Daeng (2008) bahwa kebudayaan merupakan pola-pola pemikiran serta tindakan tertentu yang terungkap dalam aktifitas. Kebudayaan mempunyai 3 (tiga) wujud yaitu: pola pikir (cultural system), perilaku (social system), dan karya manusia (artifact). Nilai sistem budaya sebagai pedoman yang mengatur tingkah laku masyarakat dapat dikaji melalui: adat-istiadat, sistem norma, aturan etika, aturan moral, aturan sopan-santun, pandangan hidup dan ideologi pribadi.

Gaya hidup adalah sarana menempa kesadaran diri untuk menciptakan budaya dan simbol-simbol berkaitan dengan identitas pribadi. Poerwanto (2008) mengungkapkan gaya hidup adalah perilaku seseorang yang ditunjukkan dalam aktivitas, minat dan opini khususnya berkaitan dengan citra diri untuk merefleksikan status sosialnya. Kebudayaan mencakup segala adat kebiasaan pada suatu masyarakat.

\section{b. Budaya Bugis-Makassar (Siri' Na Pacce)}

Budaya siri' na pacce merupakan salah satu falsafah budaya Masyarakat Bugis Makassar yang harus dijunjung tinggi. Istilah siri' na pacce sebagai sistem nilai budaya sangat abstrak dan sulit untuk didefenisikan karena siri' na pacce hanya bisa dirasakan oleh penganut budaya itu.

Bagi masyarakat Bugis-Makassar, siri' mengajarkan moralitas kesusilaan yang berupa anjuran, larangan, hak, dan kewajiban yang mendominasi tindakan manusia untuk menjaga dan mempertahankan diri dan kehormatannya. Siri' adalah rasa malu yang terurai dalam dimensi-dimensi harkat dan martabat manusia, siri' adalah sesuatu yang 'tabu' bagi masyarakat Bugis-Makassar dalam berinteraksi dengan orang lain. Sedangkan, pacce mengajarkan rasa kesetiakawanan dan kepedulian sosial tanpa mementingkan diri sendiri dan golongan ini adalah salah satu konsep yang membuatsuku Bugis-Makassar mampu bertahan dan disegani di perantauan, pacce merupakan sifat belas kasih dan perasaan menanggung beban dan penderitaan orang lain. Jika pembahasan nilai siri' dan pacce' di atas dikaitkan dengan wujud kepatuhan dalam membayar kewajiban pajaknya dapat dilihat keterhubungannya melalui uraian sebelumnya dan makna dari Siri" na Pacce yang ada pada diri masyarakat Bugis-Makassar.

\section{c. Budaya Terkait Pajak}

Definisi Budaya Pajak menurut Widodo (2010:12) adalah: "Budaya Pajak merupakan keseluruhan interaksi formal dan informal dalam suatu institusi yang menghubungkan sistem pajak nasional dengan praktik hubungan antara aparatur pajak dengan wajib pajak, yang secara historis tertanam dalam budaya nasional, termasuk ketergantungan dan ikatan yang disebabkan oleh interaksi mereka yang terus menerus".

Nilai sistem budaya sebagai pedoman yang mengatur tingkah laku masyarakat dapat dikaji melalui salah satu diantaranya aturan moral yang ada pada diri wajib pajak. Terdapat kecenderungan adanya peraturan (hukum) dan budaya masyarakat untuk meloloskan diri dari pembayaran pajak karena membayar pajak adalah suatu aktivitas yang tidak lepas dari kondisi perilaku (kebiasaan) Wajib Pajak itu sendiri (Widodo, 2010:8). Tidak ada satupun negara dimana masyarakatnya merasa senang membayar pajak tapi mereka mau membayar pajak tidak lain karena pajak merupakan Budaya (Widodo, 2010:12).

\section{METODE}

Sumber data yang digunakan dalam peneilitian ini adalah.

a. Data primer

Data primer adalah data yang secara langsung bersumber dari responden tanpa ada perantara, dalam hal ini adalah dari jawaban atas pertanyaanpertanyaan yang ada dalam kuesioner. Data primer yang dihasilkan dalam penelitian ini adalah merupakan hasil dari tanggapan responden terhadap variabel-variabel penelitian yang akan diuji.

b. Data sekunder

Data sekunder yaitu data yang diperoleh dari Kantor Pelayanan Pajak Pratama Makassar Selatan yang berkaitan dengan penelitian ini.

Penelitian ini dilaksanakan di Kantor Pelayanan Pajak Pratama Makassar Selatan di Jl. Urip Sumohardjo km 4 Gedung Keuangan 
Negara 1 Makassar. Penelitian dilaksanakan mulai bulan maret s/d april 2018 .

Untuk mengetahui pengaruh sanksi perpajakan terhadap kepatuhan wajib pajak dimoderasi budaya (siri' na pacce) maka variabel penelitian yang digunakan dalam penelitian ini adalah sanksi perpajakan, dan budaya siri' na pacce sebagai variabel bebas (independent) dan kepatuhan wajib pajak sebagai variabel terikat (dependen). Untuk lebih jelasnya dapat diuraikan sebagai berikut:

Menurut Sugiyono (2013:61) populasi adalah "Wilayah generalisasi yang terdiri atas objek/subjek yang mempunyai kualitas dan karakteristik tertentu yang ditetapkan oleh peneliti untuk dipelajari dan kemudian ditarik kesimpulannya". Adapun populasi dalam penelitian ini yaitu wajib pajak orang pribadi (WPOP) yang terdaftar di Kantor Pelayanan Pajak Makassar Selatan, yaitu sebayak 147.489 orang ditahun 2017.

Sampel menurut Sugiyono (2013:62) adalah bagian dari jumlah maupun karakteristik populasi. Sampel adalah bagian dari populasi yang diharapkan dapat mewakili populasi penelitian. Pengambilan sampel dalam penelitian ini dilakukan dengan menggunakan metode simple random sampling. Sampelnya merupakan wajib pajak orang pribadi (WPOP) yang ditemui oleh peneliti secara acak di lokasi penelitian. Metode penentuan sampel yang digunakan dalam penelitian ini adalah dengan rumus slovin (Budianty, 2015).

Data dikumpulkan dengan cara mendatangi langsung alamat Kantor Pelayanan Pajak Pratama Makassar Selatan. Teknik pengumpulan data yang digunakan pada penelitian ini antara lain:

a. Library Research

Data dikumpulkan dengan mengambil data atau teori dari buku-buku referensi atau menggunakan teknologi canggih internet yang berhubungan dengan judul yang diangkat pada penelitian ini.

b. Field Research ( Metode Penelitian Lapangan)

Merupakan suatu penelitian yang dilakukan secara langsung dengan objek penelitian. Terdapat beberapa cara dalam mengumpulkan data, antara lain:

1) Observasi dilakukan dengan mendatangi langsung tempat penelitian terhadap objek penelitian.

2) Daftar Pertanyaan ( kuesioner)
Kuesioner yang diberikan kepada responden merupakan kuesioner tertutup yang disertai dengan penjelasan dan petunjuk pengisian yang dibuat secara sederhana namun dapat dipahami oleh responden sehingga dapat meminimalisir kesalahan dalam pengisian jawaban.

\section{c. HASIL DAN PEMBAHASAN}

\section{Hasil}

Populasi dalam penelitian ini adalah wajib pajak orang pribadi yang terdaftar di Kantor Pelayanan Pajak Peratama Makassar Selatan. Pengumpulan data dalam penelitian ini dilakukan dengan penyebaran kuesioner kepada responden yang ditemui secara acak di Kantor Pelayanan Pajak Peratama Makassar Selatan. Proses pendistribusian data dilakukan selama kurang lebih dua bulan.

Data responden dapat dilihat pada tabel dibawah ini yang menyajikan beberapa informasi umum mengenai kondisi responden yang ditemukan pada penyebaran kuesioner yang ditunjukkan pada tabel berikut ini :

Tabel 2. Distribusi Pengembalian Kuesioner

\begin{tabular}{lll}
\hline Keterangan & Jumlah & Persentase \\
\hline Kuesioner yang kembali & 66 & $66 \%$ \\
\hline $\begin{array}{l}\text { Kuesioner yang tidak } \\
\text { kembali/cacat }\end{array}$ & 34 & $34 \%$ \\
\hline Total kuesioner & 100 & $100 \%$ \\
\hline
\end{tabular}

Sumber: Data diolah Oleh Peneliti (2018)

Jumlah populasi sebanyak 100 responden di Kantor Pelayanan Pajak Pratama Makassar Selatan, yang terdiri dari wajib pajak orang pribadi (WPOP) yang ditemui secara acak di lokasi. Penelitian ini secara langsung memberikan kuesioner kepada 100 responden, tetapi peneliti hanya memperoleh kembali kuesioner sebanyak 66 kuesioner yaitu sebanyak $66 \%$ sedangkan kuesioner yang tidak kembali sebanyak 34 orang atau sebesar $34 \%$. Adapun dari 34 kuesioner yang tidak kembali disebabkan karena pengisian kuesioner dinyatakan cacat. Dari tabel distribus kuesioner diatas akan Nampak pada grafik IV.1 berikut ini: 


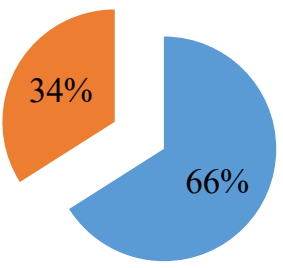

Kuesioner yang kembali

Gambar 1

Tingkat Pengembalian Kuesioner

Sumber : Data Diolah Oleh Peneliti (2018)

Jumlah pernyataan dalam kuesioner tersebut yaitu sebanyak 16 item. Pernyataan untuk variabel sanksi pajak atau X1 terdiri dari 6 pernyataan, sedangkan pernyataan pada variabel kepatuhan wajib pajak atau X2 terdiri dari 6 pernyataan, dan pada variabel budaya sebanyak 4 pernyataan. Berikut ini beberapa pernyataan yang dibagikan peneliti kepada responden.

1. Karakteristik Responden Berdasarkan Jenis Kelamin

Untuk mengatahui karakteristik responden berdasarkan jenis kelamin dapat dilihat pada tabel IV.2 berikut ini :

Tabel 3. Karakteristik responden berdasarkan jenis kelamin

\begin{tabular}{|c|c|c|}
\hline $\begin{array}{l}\text { Jenis Kelamin Responde } \\
\text { (WPOP) }\end{array}$ & Jumlah & Persentase \\
\hline Pria & 37 & $56 \%$ \\
\hline Wanita & 29 & $44 \%$ \\
\hline Total & 66 & $100 \%$ \\
\hline
\end{tabular}

Sumber: Data diolah Oleh Peneliti (2018)

Dari data karakteristik responden berdasarkan jenis kelamin pada tabel di atas, maka jumlah responden terbesar adalah responden yang berjenis kelamin pria yaitu sebanyak 37 orang atau 56\%. Sedangkan jumlah responden terendah adalah responden yang berjenis kelamin wanita yaitu sebanyak 29 orang atau 44\%. Maka dapat disimpulkan bahwa sebagian besar wajib pajak orang pribadi yang terdaftar di KPP Peratama Makassar Selatan adalah berjenis kelamin pria. Dari tabel diatas dapat di lihat pada grafik IV.2 dibawah ini :

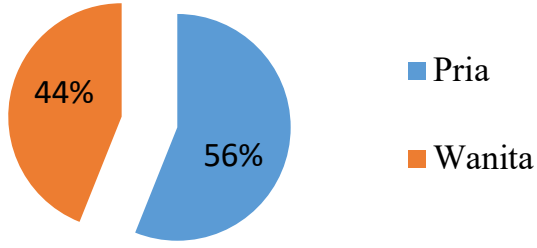

Gambar 2

Karakteristik Responden

Berdasarkan Jenis Kelamin

Sumber : Data Diolah Oleh Peneliti (2018)

\section{Karakteristik Responden Berdasarkan Usia}

Tabel 4. Karakteristik responden berdasarkan usia

\begin{tabular}{lll}
\hline Usia (Tahun) & Jumlah & Persentase \\
\hline$\leq 20$ & 0 & 0 \\
\hline $21-30$ & 16 & $24 \%$ \\
\hline $31-40$ & 37 & $56 \%$ \\
\hline$\geq 41$ & 13 & $20 \%$ \\
\hline Total & 66 & $100 \%$
\end{tabular}

Sumber: Data diolah Oleh Peneliti (2018)

Berdasarkan tabel data karakteristik responden berdasarkan usia diatas dapat diketahui bahwa tidak ada responden yang berusia $\leq 20$ tahun, sedangkan responden yang berusa 21-30 tahun berjumlah 16 orang atau sebanyak 24\%, usia 31-40 tahun sebanyak 37 orang atau $56 \%$ dan responden yang berusia $\geq 41$ tahun sebanyak 13 orang atau $20 \%$. Dengan demikian, dapat disimpulkan bahwa mayoritas responden dalam penelitian ini berusia 31-40 tahun yang merupakan wajib pajak orang pribadi yang terdaftar di Kantor Pelayanan Pajak Peratama Makassar Selatan. Dari tabel diatas dapat di lihat pada grafik berikut ini :

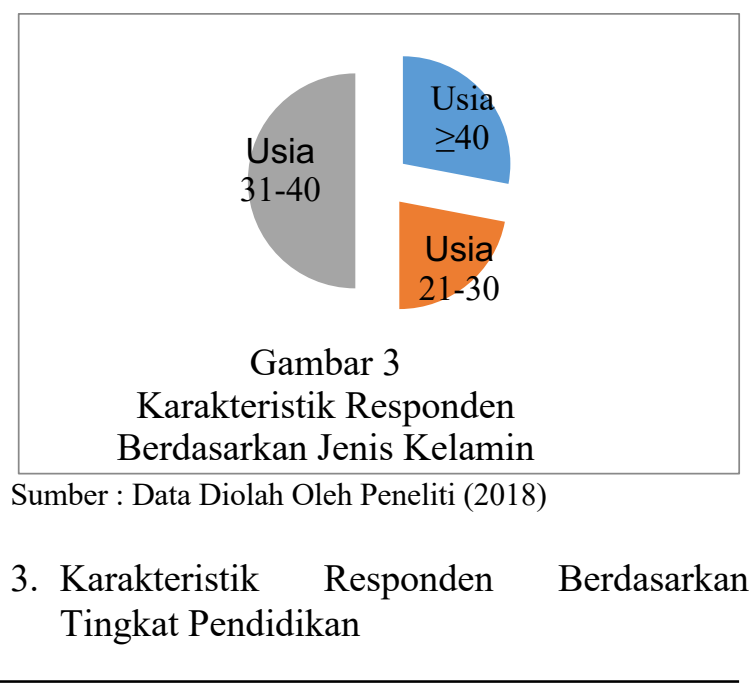


Untuk mengatahui karakteristik responden berdasarkan pendidikan terakhirdapat dilihat pada tabel berikut ini:

Tabel 5. Distribusi Responden Berdasarkan Tingkat Pendidikan

\begin{tabular}{lll}
\hline Pendidikan Terakhir & Jumlah & Persentase \\
\hline SMA & 14 & $21 \%$ \\
\hline D3 & 21 & $32 \%$ \\
\hline S1 & 24 & $36 \%$ \\
\hline S2 & 7 & $11 \%$ \\
\hline Total & 66 & $100 \%$ \\
\hline
\end{tabular}

Sumber : Data Diolah Oleh Peneliti (2018)

Berdasarkan tabel diatas dapat diketahui bahwa responden dengan pendidikan terakhir SMA sebanyak 14 orang atau $21 \%$, D3 sebanyak 21 orang atau $32 \%$, S1 sebanyak 24 orang atau $36 \%$, S2 sebanyak 7 orang atau $11 \%$, dan tidak adanya responden dengan pendidikan terakhir S3. Sehingga dapat disimpulkan bahwa mayoritas pendidikan terakhir responden wajib pajak yang terdaftar di KPP Peratama Makassar Selatan adalah S1 dan dapat di lihat pada grafik di bawah ini :

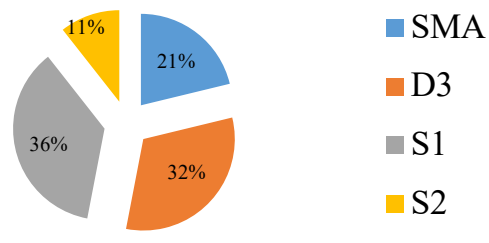

Gambar 4

Distribusi Responden Berdasarkan Tingkat Pendidikan

Sumber : Data Diolah Oleh Peneliti (2018)

\section{Karakteristik Responden Berdasarkan Pengisian SPT}

Untuk mengatahui karakteristik responden berdasarkan pengisian SPT dapat dilihat pada tabel berikut ini:

Tabel 6. Karakteristik responden berdasarkan pengisian SPT

\begin{tabular}{lll}
\hline Pengisian SPT & Jumlah & Persentase \\
\hline Sendiri & 64 & $97 \%$ \\
\hline Konsultan & 2 & $3 \%$ \\
\hline
\end{tabular}

\begin{tabular}{lll}
\hline Tenaga Ahli & 0 & 0 \\
\hline Total & 66 & $100 \%$ \\
\hline
\end{tabular}

Sumber: Data diolah Oleh Peneliti (2018)

Berdasarkan tabel diatas dapat diketahui bahwa responden yang melakukan pengisian SPT tahunan sendiri sebayak 64 orang atau $97 \%$, dan respondeng yang melakukan pengisian SPT menggunakan konsultan adalah sebanyak 2 orang atau 3\%, sedangkan tidak ada respondeng yang menggunakan tenagah ahli dalam pengisian SPT. Maka dapat disimpulkan bahwa pengisian SPT wajib pajak orang pribadi di KPP Pratama Makassar Selatan adalah WOP itu sendiri. Dari kesimpulan tersebut dapat di lihat pada grafik di bawah ini :

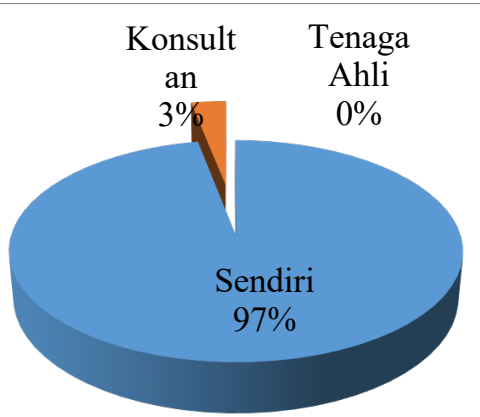

Gambar 5

Distribusi Responden berdasarkan pengisian SPT

Sumber: Data diolah Oleh Peneliti (2018)

\section{Hasil Uji Validitas dan Reliabilitas}

Sebelum data yang terkumpul dianalisis perlu dilakukan uji validitas dan reliabilitas. Pengujian ini akan menentukan layak data untuk dianalisis lebih lanjut. Berdasarkan uji validitas dan reliabilitas instrumen penelitian yang dilakukan terhadap seluruh item yang digunakan, hasilnya menunjukkan bahwa seluruh item yang ditetapkan dalam penelitian ini adalah valid dan reliable. Oleh karena itu kuesionernya layak untuk digunakan sebagai instrumen dalam penelitian ini.

\section{Hasil Uji Validitas Dan Reliabilitas Sanksi Pajak (X1)}

Berikut ini adalah hasil uji validitas dan reliabilitas Sanksi Pajak yang ditunjukan pada table 7 sebagai berikut:

Tabel 7. Uji Validitas Dan Reliabilitas Sanksi Pajak (X1)

\begin{tabular}{ccccccc}
\hline \multirow{2}{*}{ Variabel } & \multicolumn{4}{c}{ Validitas } & \multicolumn{2}{c}{ Reliabilitas } \\
\cline { 2 - 4 } & $\begin{array}{c}\text { Pearson } \\
\text { Corelation }\end{array}$ & r Hitung & r Tabel & Ket. & Cronbach Alpha & Ket. \\
\hline X1.1 & 0,632 & 0.523 & 0,204 & \multirow{2}{*}{ Valid } & 0,722 & Reliable \\
\hline \hline
\end{tabular}




\begin{tabular}{cccc}
\hline & & & \\
\hline $\mathrm{X} 1.3$ & 0,536 & 0.423 & 0,204 \\
\hline $\mathrm{X} 1.4$ & 0,539 & 0.412 & 0,204 \\
\hline $\mathrm{X} 1.5$ & 0,504 & 0.392 & 0,204 \\
\hline $\mathrm{X} 1.6$ & 0,532 & 0.416 & 0,204 \\
\hline
\end{tabular}

Dalam tabel 6 terlihat bahwa variabel sanksi pajak terdapat 06 buah pertanyaan. Berdasarkan hasil uji validitas menunjukan nilai $\mathrm{r}$ hitung $0,523>$ nilai $r$ tabel 0,204 . Dengan demikian dapat di simpulkan bahwa semua item variabel indepeden (Sanksi Pajak) yang nilai $r$ hitung $>r$ tabel berarti berkoredasi positif atau memenuhi syarat valid. Sedangkan hasil uji reliabilitasnya, nilai cronbach alpha adalah 0,772 yang berarti variabel sanksi pajak tersebut reliable karena memiliki koefesien alpha diatas 0,60 .

\section{Hasil Uji Validitas Dan Reliabilitas Sanksi Pajak (X2)}

Berikut ini adalah hasil uji validitas dan reliabilitas budaya pajak yang ditunjukan pada table 4.7 sebagai berikut:

Tabel 8. Uji Validitas Dan Reliabilitas Budaya Pajak (X2)

\begin{tabular}{|c|c|c|c|c|c|c|}
\hline \multirow[b]{2}{*}{ Variabel } & \multicolumn{4}{|c|}{ Validitas } & \multicolumn{2}{|c|}{ Reliabilitas } \\
\hline & $\begin{array}{c}\text { Pearson } \\
\text { Corelation }\end{array}$ & r Hitung & r Tabel & Ket. & Cronbach Alpha & Ket. \\
\hline $\mathrm{X} 2.1$ & 0,614 & 0.456 & 0,204 & \multirow{4}{*}{ Valid } & \multirow{4}{*}{0,738} & \multirow{4}{*}{ Reliable } \\
\hline $\mathrm{X} 2.2$ & 0,776 & 0.676 & 0,204 & & & \\
\hline $\mathrm{X} 2.3$ & 0,574 & 0.425 & 0,204 & & & \\
\hline $\mathrm{X} 2.4$ & 0,539 & 0.373 & 0,204 & & & \\
\hline
\end{tabular}

Sumber : Data Olahan (2018)

Dalam tabel 8 terlihat bahwa variabel sanksi pajak terdapat 04 buah pertanyaan. Berdasarkan hasil uji validitas menunjukan nilai $r$ hitung $0,456>$ nilai $r$ tabel 0,204 . Dengan demikian dapat di simpulkan bahwa semua item variabel indepeden (budaya pajak) yang nilai $r$ hitung $>$ $r$ tabel berarti berkoredasi positif atau memenuhi syarat valid. Sedangkan hasil uji reliabilitasnya, nilai cronbach alpha adalah 0,738 yang berarti variabel budaya siri na' pacce tersebut reliable karena memiliki koefesien alpha diatas 0,60 .

\section{Hasil Uji Validitas Dan Reliabilitas Kepatuhan Wajib Pajak (Y)}

Berikut ini adalah hasil uji validitas dan reliabilitas kepatuhan wajib pajak yang ditunjukan pada table 4.8 sebagai berikut:

Tabel 9. Uji Validitas Dan Reliabilitas Kepatuhan Wajib Pajak (Y)

\begin{tabular}{|c|c|c|c|c|c|c|}
\hline \multirow[b]{2}{*}{ Variabel } & \multicolumn{4}{|c|}{ Validitas } & \multicolumn{2}{|c|}{ Reliabilitas } \\
\hline & $\begin{array}{l}\text { Pearson } \\
\text { Corelation }\end{array}$ & r Hitung & r Tabel & Ket. & Cronbach Alpha & Ket. \\
\hline Y1 & 0,526 & 0.420 & 0,204 & \multirow{6}{*}{ Valid } & \multirow{6}{*}{0,736} & \multirow{6}{*}{ Reliable } \\
\hline Y2 & 0,612 & 0.507 & 0,204 & & & \\
\hline Y3 & 0,557 & 0.450 & 0,204 & & & \\
\hline Y4 & 0,698 & 0.606 & 0,204 & & & \\
\hline Y5 & 0,626 & 0.527 & 0,204 & & & \\
\hline Y6 & 0,513 & 0.403 & 0,204 & & & \\
\hline
\end{tabular}

Sumber : Data Olahan (2018)

Dalam tabel 4.8 terlihat bahwa variabel kepatuhan wajib pajak terdapat 06 buah pertanyaan. Berdasarkan hasil uji validitas menunjukan nilai $r$ hitung $0,420>$ nilai $r$ tabel 0,204 . Dengan demikian dapa di simpulkan bahwa semua item variabel depeden (Kepatuhan Wajib Pajak) yang nilai $r$ hitung $>r$ tabel berarti berkoredasi positif atau memenuhi syarat valid. Sedangkan hasil uji reliabilitasnya, nilai cronbach alpha adalah 0,736 yang berarti variabel kepatuhan wajib pajak tersebut reliable karena memiliki koefesien alpha diatas 0,60.

\section{Hasil Uji Asumsi Klasik}

a. Hasil Uji Normalitas

Uji normalitas adalah langka awal yang harus dilakukan untuk setiap analisis multiviate khususnya jika tujuanya adalah inferensi. Jika 
terdapat normalitas maka akan terdistribusi secara normal.

Pada penelitian ini untuk menguji normalitas menggunakan normal probability plot, kriteria yang digunakan adalah jika masing-masing variabel menghasilkan nilai $\mathrm{p}>0.05$ maka dapat disimpulkan bahwa masing-masing data pada variabel probability plot yang diteliti terdistribusi secara normal. Hasil uji normalitas disajikan sebagai berikut terlihat pada gambar 4.1 dibawah ini :

Normal P-P Plot of Regression Standardized Residual

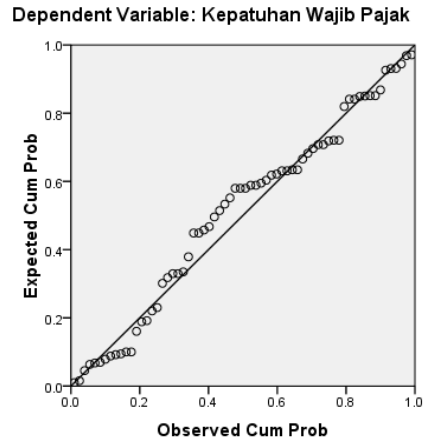

Gambar 6 Uji Normalitas

Sumber : Hasil Data Olahan (2018)

Dari nomal probability plot di atas dapat dilihat secara seksama bahwa data menyebar sekitar garis diagonal atau mengukuti dan mendekati garis diagonalnya sehingga dapat disimpulkan bahwa model regresi memenuhi asumsi normalitas.

\section{b. Hasil Uji Autokorelasi}

Untuk mendeteksi autokorelasi dapat dilakukan dengan melihat angka DurbinWatson, terlihat pada tabel 4.9 dibawah ini:

Tabel 10. Hasil Uji Autokorelasi

\begin{tabular}{|c|c|c|c|c|}
\hline \multicolumn{5}{|c|}{ Model Summary ${ }^{b}$} \\
\hline Model R & $\begin{array}{l}\mathrm{R} \\
\text { Square }\end{array}$ & $\begin{array}{l}\text { Adjusted } \\
\text { R Square }\end{array}$ & $\begin{array}{l}\text { Std. Error } \\
\text { of the } \\
\text { Estimate }\end{array}$ & $\begin{array}{l}\text { Durbin- } \\
\text { Watson }\end{array}$ \\
\hline $.636^{\mathrm{a}}$ & .404 & .385 & 1.96065 & 1.894 \\
\hline $\begin{array}{l}\text { a. Predictors: } \\
\text { Pajak }\end{array}$ & (Cons & ant), Buda & ya, Sanks & \\
\hline
\end{tabular}

Berdasarkan tabel 4.9 di atas terlihat bahwa angka durwin whotson sebesar 1,894 nilai akan dibandingkan dengan nilai tabel menggunakan signifikan $5 \%$ dan jumlah sample 66 dengan jumblah variabel 3 maka di tabel durwin whotson akan diperoleh nilai sebesar sebagai berikut:

Dari data di atas dapat disimpulkan bahwa nilai durwin whotson sebesar 1,894 berada di $1<$ DW $<3$ maka dapat dikatakan bahwa dalam model regresi linier tersebut tidak terdapat autokorelasi atau tidak terjadi korelasi diantara kesalahan pengganggu.

\section{c. Hasil Uji Heterokedastisitas}

Untuk mendeteksi heterokedastisitas dapat melalui grafik scatterplot deteksinya dengan melihat ada tidaknya pola tertentu pada grafik dimana sumbu $\mathrm{X}$ dan $\mathrm{Y}$ menyebar di atas dan bawah angka 0 pada sumbu Y. Seperti terlihat pada gambar 4.3 dibawah ini:

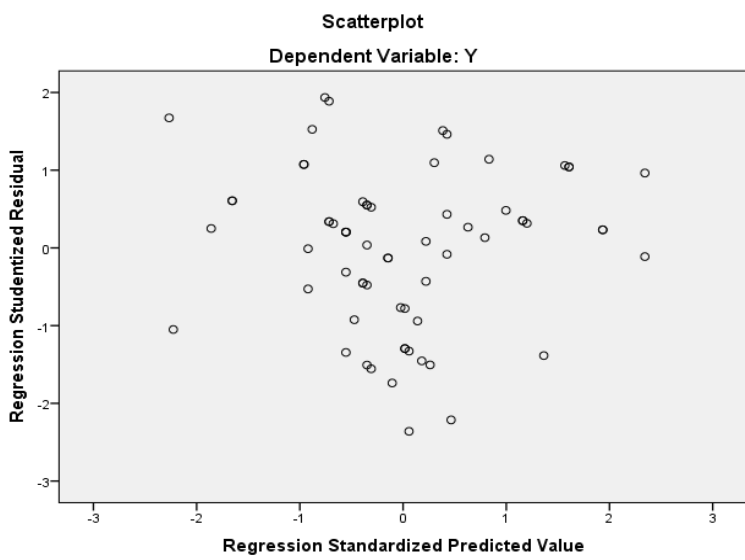

Gambar 7. Diagram Scatterplot Heterokedastisitas

Sumber : Hasil Data Olahan (2018)

Pada gambar 4.3 jelas bahwa tidak ada pola tertentu karena titik menyebar tidak beraturan di atas dan di bawah sumbu 0 pada sumbu Y. Maka dapat di simpulkan tidak terdapat gejala heteroskedastistas atau $\mathrm{HO}$ di terima yang berarti modal regresi ini layak untuk memprediksikan variabel dependen berdasarkan masukan variabel independen.

\section{Hasil Pengujian Hipotesis}

a. Hasil Uji Regresi Secara Parsial (Uji t )

Uji ini mengetahui dari masing-masing variabel independen terhadap variabel dependen. Jika nilai signifikansi a $<0,05$, maka dapat di katakana bahwa terdapat pengaruh signifikan antara variabel independen dengan variabel dependen secara individu, sebalik jika signifikansi $\alpha>0,05$ maka tidak terjadi pengaruh yang signifikan. Berikut hasil uji 
regresi (uji t) dicamtumkan dalam tabel 4.10

sebagai berikut:

Tabel 11. Hasil Pengujian Hipotesis

\begin{tabular}{|c|c|c|c|c|c|c|c|c|}
\hline \multicolumn{9}{|c|}{ Coefficients $^{\mathbf{a}}$} \\
\hline \multicolumn{2}{|c|}{ Model } & \multicolumn{2}{|c|}{ Unstandardized Coefficients } & \multirow{2}{*}{$\begin{array}{l}\text { Standardized } \\
\text { Coefficients } \\
\text { Beta }\end{array}$} & \multirow[t]{2}{*}{$\mathrm{t}$} & \multirow[t]{2}{*}{ Sig. } & \multicolumn{2}{|c|}{ Collinearity Statistics } \\
\hline & & $\mathrm{B}$ & Std. Error & & & & Tolerance & VIF \\
\hline \multirow[t]{3}{*}{$\overline{1}$} & (Constant) & 6.809 & 2.758 & & 2.469 & .016 & & \\
\hline & Sanksi Pajak & .324 & .111 & .319 & 2.915 & .005 & .792 & 1.262 \\
\hline & Budaya & .584 & .150 & .424 & 3.880 & .000 & .792 & 1.262 \\
\hline
\end{tabular}

a. Dependent Variable: Kepatuhan Wajib Pajak

1) Variabel Sanksi Pajak (X1) menunjukan Coefficients Beta sebesar 0,319 pada tingkat signifikansi 0,05 , karena tingkat signifikansi $0,05<0,05$. Hal ini berarti variabel Sanksi Pajak (X1) berpengaruh secara signifikan terhadap Kepatuhan Wajib Pajak (Y).

2) Variabel Budaya (X2) menunjukan Coefficients Beta sebesar 0,424 pada tingkat signifikansi $0,000, \quad$ karena tingkat signifikansi $0,000<0,05$. Hal ini berarti variabel Budaya (X2) berpengaruh secara signifikan terhadap Kepatuhan Wajib Pajak (Y).

\section{Uji korelasi}

Pada tabel 4.9 terlihat bahwa Nilai R 0,636 dan angka Durbin-Watson sebesar 1,894 nilai akan di bandingkan dengan nilai tabel dengan menggunakan signifikan 5\%. Hal ini berarti adanya korelasi antara variabel $\mathrm{X}$ dan variabel Y. Hasil pengujian ini menunjukan nilai $r>0$ dan $<1$, maka korelasi antara kedua variabel dapat dikatakan positif dan searah, dengan kata lain kenaikan atau penurunan nilai-nilai variabel independen yang terjadi bersama-sama dengan kenaikan atau penurunan variabel dependen.

\section{Koefisien Determinasi}

Koefisien determinasi dilakukan untuk mengetahui seberapa besar pengaruh Sanksi Pajak, Budaya terhadap Kepatuhan Wajib Pajak dan seberapa besar yang dipengaruhi oleh faktor-faktor lain. Dari hasil penghitungan sebelumnya pada tabel 4.9 , R Square adalah 0,404 . Hal ini berarti koefisien determinasi yaitu sebesar 0,404 atau $40,4 \%$.

Dari perhitungan tersebut menunjukkan besarnya sanksi pajak, serta budaya terhadap kepatuhan wajib pajak adalah sebesar 40,4\%. Sedangkan sisanya 59,6\% merupakan besarnya pengaruh dari faktor lain di luar Sanksi Pajak, Budaya.

\section{Uji Moderated Regression Analysis}

Moderated Regression Analysis (MRA) merupakan aplikasi dari regresi linear berganda dimana dalam persamaan regresinya mengandung unsur interaksi (perkalian dua atau lebih variabel independen). Berikut Hasil MRA ini menggunakan program SPSS yang sudah tercamtum pada tabel dibawah ini:

Tabel 12. Hasil Moderated Regression Analysis

\begin{tabular}{|c|c|c|c|c|c|c|c|c|}
\hline \multicolumn{9}{|c|}{ Coefficients $^{\mathbf{a}}$} \\
\hline \multirow{2}{*}{\multicolumn{2}{|c|}{ Model }} & \multicolumn{2}{|c|}{ Unstandardized Coefficients } & \multirow{2}{*}{$\begin{array}{l}\text { Standardized } \\
\text { Coefficients } \\
\text { Beta }\end{array}$} & \multirow[t]{2}{*}{$\mathrm{t}$} & \multirow[t]{2}{*}{ Sig. } & \multicolumn{2}{|c|}{ Collinearity Statistics } \\
\hline & & $\mathrm{B}$ & Std. Error & & & & Tolerance & VIF \\
\hline \multirow[t]{3}{*}{1} & (Constant) & 6.809 & 2.758 & & 2.469 & .016 & & \\
\hline & Sanksi Pajak & .324 & .111 & .319 & 2.915 & .005 & .792 & 1.262 \\
\hline & Budaya & .584 & .150 & .424 & 3.880 & .000 & .792 & 1.262 \\
\hline
\end{tabular}

a. Dependent Variable: Kepatuhan Wajib Pajak

Sumber : Hasil Data Olahan (2018) 
Berdasarkan tabel 12 dapat di simpulkan bahwa hasil analisis data di atas, maka hasil persamaan regresi adalah sebagai berikut:

$\mathrm{Y}=\alpha+\beta 1 \mathrm{X} 1+\beta 2 \mathrm{X} 2+\varepsilon$

$\mathrm{Y}=6.809+0,324 \mathrm{X} 1+0,584 \mathrm{X} 2+\varepsilon$

Keterangan:

- Konstanta (a).

- Ini berarti jika semua semua variabel bebas memiliki nilai nol (0) maka nilai variabel terikat sebesar 6.809.

- Sanksi Pajak (X1) terhadap Kepatuhan Wajib Pajak (Y).

- Nilai koefisien leverage untuk variabel X1 sebesar 0,324 . Hal ini mengandung arti bahwa setiap kenaikan sebesar 1, maka variabel dependen juga mengalami peningkatan sebear $0,324 \%$.

- Budaya (X2) terhadap Kepatuhan Wajib Pajak (Y).

- Nilai koefisien leverage untuk variabel X2 sebesar 0,584 . Hal ini mengandung arti bahwa setiap kenaikan sebesar 1, maka variabel dependen juga mengalami peningkatan sebesar $0,584 \%$.

\section{Pembahasan}

a. Hasil temuan hipotesis $\mathrm{H} 1$ dan pembahasan

Hasil temuan pertama dalam penelitian ini menyatakan bahwa terdapat pengaruh yang positif dan signifikan atas variabel sanksi pajak terhadap variabel kepatuhan wajib pajak. Ini berarti bahwa semakin tinggi sanksi pajak maka akan semakin tinggi tingkat kepatuhan wajib pajak. Adanya pengenaan sanksi pajak dapat meningkatkan kesadaran akan hak dan kewajiban wajib pajak dalam perpajakan. Wajib pajak akan mematuhi pembayaran pajak bila memandang sanksi akan lebih menambah biaya. Oleh sebab itu hepotesis H1 dalam penelitian ini diterima. Hasil penelitian ini sejalan dengan penelitian yang dilakukan oleh Ardyanto dan Utaminingsi (2014), dimana hasil penelitiannya adalah sanksi perpajakan berpengaruh positif dan signifikat terhadap tingkat kepatuhan wajib pajak.

b. Hasil temuan hipotesis $\mathrm{H} 2$ dan pembahasan

Hasil temuan kedua dalam penelitian ini menyatakan bahwa terdapat pengaruh atas variabel saksi pajak terhadap variabel kepatuhan wajib pajak dimoderasi budaya. Hadirnya budaya akan meningkatkan kejujuran wajib pajak dalam melaporkan jumlah pajak yang terutang sehingga memperkuat hubungan sanksi pajak terhadap kepatuhan wajib pajak. Hal tersebut merupakan salah satu bentuk kesetiaan dan pengabdian wajib pajak terhadap negara. Yang artinya bahwa semakin tinggi pelaksanaan sanksi yang diberikan kepada wajib pajak maka akan menambah pengeluaran yang harus dibayar wajib pajak ditambah rasa malu dari budaya yang sudah tertanam pada individu wajib pajak sehingga dapat memperkuat hubungan antara budaya terhadap kepatuhan wajib pajak dalam membayar pajak pribadi. . Oleh sebab itu hepotesis $\mathrm{H} 2$ dalam penelitian ini diterima. Hasil penelitian ini sejalan dengan penelitian yang dilakukan oleh Muthia (2013) dimana hasil penelitiannya menunjukkan bahwa moral dan budaya pajak memiliki pengaruh yang signifikan terhadap kepatuhan pajak.

\section{KESIMPULAN}

\section{Kesimpulan}

Berdasarkan hasil analisis dan pembahasan yang telah dilakukan yaitu mengenai pengaruh sanksi perpajakan terhadap tingkat kepatuhan wajib pajak orang pribadi yang dimoderasi budaya bugis makassar dapat diberikan kesimpulan sebagai berikut.

a. Sanksi perpajakan berpengaruh positif dan signifikat sehingga dapat meningkatkan kepatuhan wajib pajak di KPP Makasaar Selatan, hal ini berarti dengan pengenaan sanksi perpajakan yang berupa denda apabila WPOP mengalami keterlambatan dalam pelaporan SPT tahunannya sebanyak Rp 100.000 per tahun, serta sanksi pidana yang benar-benar dipertegas oleh pemerintah akan meningkatkan kesadaran akan hak dan kewajiban wajib pajak dalam membayar pajak pribadinya.

b. Sanksi pajak berpengaruh secara positif dan signifikan terhadap kepatuhan wajib pajak (WPOP) yang dimoderasi budaya bugis makassar atau yang kental dengan siri na pacce dapat memperkuat kesadaran wajib pajak di Kantor Pelayanan Pajak Pratama Makassar Selatan, hal ini berarti sanksi pajak berpengaruh dalam meningkatkan kepatuhan yang didorong oleh budaya siri na'pacce.

\section{Saran}

a. Bagi Kantor Pelayanan Pajak Pratama Makassar Selatan

Berdasarkan dari hasil penelitian bahwa sanksi perpajakan berpengaruh signifikan terhadap kepatuhan wajib pajak orang pribadi yang terdaftar di KPP Pratama Makassar Selatan. Dengan demikian KPP Pratama Makassar Selatan harus melakukan pengenaan 
sanksi pajak yang tegas bagi yang melanggar kewajibannya sebagai wajib pajak, selain itu sanksi perpajakan yang dilakukan harus sesuai dengan besar kecilnya pelanggaran yang dilakukan wajib pajak, serta sanksi pajak yang diterapkan harus adil pada setiap pelaku pelanggar pajak tanpa membedakan siapapun dia (termasuk para pejabat publik maupun keluarganya) yang melakukan pelanggaran pajak.

b. Bagi Civitas Akademika

Bagi peneliti yang tertarik ingin melakukan penelitian selanjutnya khususnya tentang pengaruh sanksi perpajakan terhadap kepatuhan wajib pajak orang pribadi, peneliti dapat menambahkan variabel diluar variabel sanksi perpajakan yang merupakan variabel pendukung. Misalnya adalah variabel penyuluhan, kesadaran wajib pajak, motivasi, pengetahuan dan kualitas pelayanan. Agar memperoleh hasil yang lebih bervariatif yang dapat menggambarkan hal-hal apa saja yang dapat berpengaruh terhadap kepatuhan membayar pajak.

\section{REFERENSI}

Adiasa. 2013. Pengaruh Pemahaman Peraturan Perpajakan terhadap Kepatuhan Wajib Pajak dengan Preferensi Risiko sebagai Variabel Moderating. Skripsi. Program Akuntansi Fakultas Ekonomi dan Bisnis Universitas Negeri Semarang.

Amalia.R,Topowijono dan Dwiatmanto, 2016. Pengaruh Pengenaan Sanksi Administrasi Dan Kesadaran Wajib Pajak Terhadap Tingkat Kepatuhan Wajib Pajak Kendaraan Bermotor. Jurnal Administrasi Bisnis. Vol. 31 No.1.

Ardyanto dan Utaminingsih, 2014. Pengaruh Sanksi Pajak Dan Pelayanan Aparat Pajak Terhadap Kepatuhan Wajib Pajak Dengan Preferensi Risiko Sebagai Variabel Moderasi. Jurnal Analisis Akuntansi. Vol 3 No.2

Arikunto, Suharsimi. 2002. Prosedur Penelitian: Suatu Pendekatan Praktek (Edisi Revisi V). Jakarta: Rineka Cipta.

Candra, Ricki, Wibisono, Haris, dan Mujilan. 2013. "Modernisasi Sistem Administrasi
Perpajakan dan Kepatuhan Wajib Pajak". Jurnal Riset Manajemen Dan Akuntansi. Vol. 1(1): hal. 40-48.

Dina Fitri Septarini. 2015 "Pengaruh Pelayan, Sanksi Dan Kesadaran Wajib Pajak Terhadap Kepatuhan Wajib Pajak Orang Pribadi di KPP Pratama Merauke". Jurnal Ilmu Ekonomi \& Sosial, Volume VI No. 1

Doni Sapriadi. 2013 Pengaruh Kualitas Pelayanan Pajak, Sanksi Pajak dan Kesadaran Wajib Pajak Tehadap Kepatuhan WP dalam Membayar PBB (Pada Kecamatan Selupu Rejang). Skripsi. Program Studi Akuntansi Fakultas Ekonomi Universitas Negeri Padang.

Hasan, Ikbal. 2010. Pokok-pokok Materi Statistik 1 (statistik deskriptif). Jakarta:Bumi Aksara.

Hamid, A., Farid, Z. A., Mattulada., Lopa, B., \& Salombe,C. (2007). Siri' \& Pesse: Harga diri manusia bugis, Makassar, Mandar, Toraja. Makassar: Pustaka Refleksi.

Harinurdin, Erwin. 2009. Perilaku Kepatuhan Wajib Pajak Badan. Jurnal ilmu administrasi dan organisasi volume 16 nomor 2. hlm.96-104.

Ida Bagus Ngurah Ari Putra Wirawan dan Naniek Noviari. 2017. Pengaruh Penerapan Kebijakan Tax Amnesty dan Sanksi Perpajakan Terhadap Kepatuhan Wajib Pajak Orang Pribadi. E-Jurnal Akuntansi Universitas Udayana. Vol.21.3.

Jatmiko, Agus N. 2009. Pengaruh Sikap Wajib Pajak Pada Pelaksanaan Sanksi Denda, Pelayanan Fiskus Dan Kesadaran Perpajakan Terhadap Kepatuhan Wajib Pajak (Studi Empiris Terhadap Wajib Pajak Orang Pribadi Di Kota Semarang). Tesis Magister. FEB UNDIP.Semarang

Lingga, Ita Salsalina. 2012. "Pengaruh Penerapan e-SPT PPN Terhadap Efisiensi Pengisian SPT Menurut Persepsi Wajib Pajak: Survey Terhadap 
Pengusaha Kena Pajak Pada KPP Pratama X". Jurnal Akuntansi. Vol. 4(1): hal. 70-86.

Mardiasmo. 2011. Perpajakan Edisi Revisi. Yogyakarta: Andi.

Nugraha, Singgih Wahyu. 2015. Tingkat Kepatuhan Wajib Pajak Orang Pribadi Masih Rendah. http://jogja.tribunnews.com/2015/02/09/ti ngkat-kepatuhanwajib-pajak-peroranganmasih-rendah. Diunduh 13 Maret 2017.

Poerwanto, H. (2008), Kebudayaan dan Lingkungan, dalam Perspektif Antropologi. Pustaka Pelajar,Yogyakarta.

Purwono, H. 2010. Dasar-Dasar Perpajakan \& Akuntansi Pajak. Jakarta: Penerbit Erlangga.

Resmi Siti. 2013. Perpajakan: Teori dan Kasus. Edisi 7. Jakarta: Salemba Empat.

Ruyadi, Khoiru. 2009. Dampak Persepsi Tanggung Jawab Sosial Perusahaan terhadap Manakemen Perpajakan. Jurnal Akuntansi dan Bisnis, 9 (1):h:61-70, Malang: Fakultas Ekonomi dan Bisnis Universitas Brawijaya.

Siahaan, Marihot Pahala. 2010. Pajak Daerah dan Retribusi Daerah. Edisi Revisi. PT Raja Grafindo Persada. Jakarta.

Santi Annisa Nirmala. 2012. Analisis Pengaruh Kesadaran Perpajakan, Sikap Rasional, Lingkungan, Sanksi Denda Dan Sikap Fiskus Terhadap Kepatuhan wajib Pajak ( Studi Empiris Pada Wpop Di Wilayah Kpp Pratama Semarang). Skripsi. Semarang. Fakultas Ekonomi dan Bisnis Universitas Deponegoro.

Savitri.F, 2017. Pengaruh Sanksi Perpajakan Terhadap Kepatuhan Wajib Pajak Orang Pribadi Di Kantor Pelayanan Pajak Pratama Madiun. Jurna Pendidikan Ekonomi Akuntansi. Vol. 5 No.1

Siti, Kurnia Rahayu. 2010.Perpajakan Indonesia Konsep dan Aspek Formal. Yogyakarta: Graha Ilmu.
Sufren dan Yonathan.N. 2013. Mahir Menggunakan SPSS secara Otodidak. Jakarta: Alex Media Komputindo.

Sugiyono. (2013). Metode Penelitian Kuantitatif, Kualitatif dan $R \& D$. Bandung: Alfabeta.CV

Sunyoto, Danang. 2011. Analisis Regresi dan Uji Hipotesis. Jakarta: CAPS.

Supriyati dan Hidayati, 2008."Pengaruh Kepatuhan Wajib Pajak". Jurnal Akuntansi dan Teknologi Informasi, Vol. 7 No. 1, Mei 2008, hal 41-50.

Sri Rustianingsih. 2011. Faktuor-Faktor yang mempengaruhi Kepatuhan Wajib Pajak. Dalam Widya Warta, 4(2).

Supadmi, 2009. Meningkatkan Kepatuhan Pajak Melalui Kualitas Pelayanan. Audit Jurnal Akuntansi dan Bisnis. Vol. 2

Tryana A.M. Tiraada. 2013. Kesadaran Perpajakan, Sanksi Pajak, Sikap Fiskus Terhadap Kepatuhan WPOP Di Kabupaten Minahasa Selatan. Jurnal EMBA. Vol.1 No.3.

Waluyo, Perpajakan Indonesia, Jakarta: Salemba Empat, 2008.

Widodo Widi. 2010. Moralitas, Budaya, dan Kepatuhan Pajak. Bandung: Alfabeta.

Wijoyanti, Mayang. 2010. Pengaruh Penagihan Pajak Dengan Surat Paksa Terhadap Kepatuhan Wajib Pajak di Kantor Pelayanan Pajak Pratama Jakarta Mampang Prapatan. Skripsi. Jakarta: Program Skripsi Fakultas Ekonomi Universitas Pembangunan Nasional "VETERAN"]

Winerungan, 2013. Sosialisasi Perpajakan, Pelayanan Fiskus Dan Sanksi Perpajakan Terhadap Kepatuhan Wpop Di Kpp Manado Dan Kpp Bitung. Jurnal EMBA. Vol 1 No. 3

Yadnyana, I Ketut. 2009."Pengaruh Moral dan Sikap Wajib Pajak pada Kepatuhan Wajib Pajak Koperasi di Kota Denpasar. 
AMNESTY: JURNAL RISET PERPAJAKAN

p-ISSN: 2714-6308 | e-ISSN: 2714-6294

pp: 78-93, Volume 1, Nomor 2, November 2018

Denpasar: Fakultas Ekonomi Universitas

Udayana. 